\title{
Early detection of diabetic nephropathy based on albumin creatinine ratio (ACR) in type 2 diabetes mellitus patients in Medan, Indonesia
}

\author{
RINA AMELIA 1, A, в, D, F, G, DINA KEUMALA SARI 2, A-c, RIRI ANDRI MUZASTI 3, D-F, \\ $\begin{array}{lll}\text { ORCID ID: 0000-0002-0419-9622 } & \text { ORCID ID: 0000-0002-1442-5304 } & \text { ORCID ID: 0000-0001-7834-0740 }\end{array}$ \\ ISTI ILMIATI FUJIATI1, A-c, F, HENDRI WIJAYA 4, 5, D-F \\ ORCID ID: 0000-0002-6896-3984 ORCID ID: 0000-0002-7309-8227
}

${ }^{1}$ Department of Community Medicine/Public Health, Faculty of Medicine, Universitas Sumatera Utara, Medan, Indonesia

${ }^{2}$ Department of Nutrition, Faculty of Medicine, Universitas Sumatera Utara, Medan, Indonesia

${ }^{3}$ Division of Nephrology and Hypertension, Department of Internal Medicine, Faculty of Medicine, Universitas Sumatera Utara, Medan, Indonesia

${ }^{4}$ Department of Pediatrics, Faculty of Medicine, Universitas Sumatera Utara, Medan, Indonesia

${ }^{5}$ H. Adam Malik General Hospital, Medan, Indonesia

A - Study Design, B - Data Collection, C - Statistical Analysis, D - Data Interpretation, E - Manuscript Preparation, F - Literature Search, G - Funds Collection

Summary Background. Diabetic nephropathy (DN) is one of the chronic microvascular complications of type 2 diabetes mellitus (T2DM). Microalbuminuria is a marker that can be used in detecting these complications so that preventive measures can be taken. Objectives. This study aimed to detect DN as T2DM complications by measurement of the urine albumin-to-creatinine ratio (ACR) as a marker and to analyze the factors that may influence the ratio in T2DM patients.

Material and methods. The study design was a correlative study with a cross-sectional approach. The study population was all T2DM patients who regularly visit the diabetic clinic and primary health care in Medan. The sample size consisted of 89 subjects, while the subjects were recruited by consecutive sampling. Data was processed using SPSS and was analyzed using descriptive statistics and one-way ANOVA.

Results. The study results showed that most T2DM patients had normal to mildly increased ACR levels in 49 subjects $(55.1 \%)$. There was a relationship between increased ACR levels with blood glucose level (BGL) $(p=0.01), \mathrm{HbA}_{1 c}(p=0.03), \mathrm{HDL}-\mathrm{C}(p=0.01)$ and triglyceride $(p=0.04)$. In contrast, increased ACR levels had no relationship with age $(p=0.27)$, duration of illness $(p=0.13)$, systolic blood pressure $(p=0.31)$, total cholesterol $(p=0.90)$ and LDL-C $(p=0.89)$, respectively.

Conclusions. The study showed that $\mathrm{BGL}, \mathrm{HbA}, \mathrm{HDL}-\mathrm{C}$ and triglyceride had a strong relationship with the increased ACR level, which is believed to be a DN marker. ACR can be a screening tool for DN in T2DM patients and other T2DM complications, such as cardiovascular complications and retinopathy.

Key words: lipids, hypolipidemic agents, creatinine, diabetes mellitus type 2, Indonesia.

Amelia R, Sari DK, Muzasti RA, Fujiati II, Wijaya H. Early detection of diabetic nephropathy based on albumin creatinine ratio (ACR) in type 2 diabetes mellitus patients in Medan, Indonesia. Fam Med Prim Care Rev 2021; 23(2): 135-138, doi: https://doi.org/10.5114/ fmpcr.2021.105903.

\section{Background}

Diabetic nephropathy (ND) is the most common cause of end-stage renal failure. About $20-40 \%$ of diabetes patient will develop diabetic nephropathy [1]. The classification of diabetic nephropathy no longer uses the microalbuminuria and macroalbuminuria terminology instead of albuminuria. Diabetic nephropathy is classified into two stages: persistent albuminuria at a level $30-299 \mathrm{mg} / 24$ hours and persistent albuminuria at a level $\geq 300 \mathrm{mg} / 24$ hours [2].

Microalbuminuria examination is essential in DM patients who are suspected of having diabetic nephropathy. The pathologic processes involved in DN are renal hypertrophy, hyperfunction and thickening of the glomerular membrane and tubules. At this stage, there are no clinical symptoms that lead to impaired renal function. Meanwhile, glomerulosclerosis continues for the next 7-10 years and ends with increased permeability of the glomerulus. This increased permeability allows albumin to escape glo- merular filtration and is found in urine [3]. Microalbuminuria is currently used as the gold standard for early detection of diabetic nephropathy. Albuminuria is a marker of glomerular damage. However, a Japanese study suggested that similar histopathologic changes in diabetic nephropathy could occur in patients without albuminuria. Hence, urine albumin may not be sufficient to identify a patient with early diabetic nephropathy. Urinary biomarkers can provide accurate results of the degree of histopathological changes in diabetic patients with early nephropathy [4].

When screening the albuminuria, the choice is to use the urine albumin-to-creatinine ratio (urine $A C R$ ) from random urine sample. 24-hour urine collection for protein/albumin measurement is still the gold standard; however, it is cumbersome to implement on a large scale, impractical for people and is often done incorrectly [5]. Random urine albumin is not sufficient, as urine albumin concentration can vary depending on urine concentration [6]. The albumin-to-creatinine ratio is the first recommended test to detect increased protein. The recom- 
mended method for evaluating albuminuria is by calculating the urine ACR with a spot urine sample. ACR is calculated by dividing the albumin concentration in milligrams by the creatinine concentration in grams. Although 24-hour retrieval is the gold standard, an alternative method for detecting protein excretion is via ACR. A spot urine sample correlates well with 24-hour urine collection in adults [7].

The classic description of DN is a slow and progressive increase in albuminuria, followed by a decrease in estimated glomerular filtration rate (eGFR) $<60 \mathrm{~mL} / \mathrm{min} / 1.73 \mathrm{~m}^{2}$, which in turn leads to end-stage renal failure [8]. Several previous studies stated that risk factors of DN are the duration of diabetes, suboptimal glycemic control, blood pressure, plasma lipids and obesity [9], as well as smoking [10]. Some of these mentioned risk factors can be manipulated.

\section{Objectives}

This study aimed to detect DN by examining the urine albumin-to-creatinine ratio (ACR) as a marker and analyze the factors that influence patients with T2DM in Medan.

\section{Material and methods}

The study design was a correlative study with a cross-sectional approach. The study population was all T2DM patients who regularly visit the diabetic clinic and primary health care in Medan for treatment and follow up of their medical condition. The sample size consisted of 89 subjects, calculated by proportion sampling formula and recruited by consecutive sampling. The inclusion criteria in this study were: (1) T2DM patients aged 35-65 years, (2) willing to participate in this study by signing the informed consent; and the exclusion criteria were (1) history of previous kidney disorders such as urinary tract stones, trauma to the urinary tract and other disorders that reduce renal function, (2) hemodialysis associated with diabetes-related kidney disorders, (3) pregnancy. The enrollment started following ethical approval from the Universitas Sumatera Utara Ethics Commission.

The data sources were primary data, namely body weight, height, blood pressure, $\mathrm{BGL}, \mathrm{HbA}_{1 \mathrm{c}}$ levels and albumin-to-creatinine ratio (ACR). Blood pressure was measured by using a digital blood pressure monitor ( ${ }^{\mathrm{TM}}$ Omron). $\mathrm{BGL}$ and $\mathrm{HbA}_{1 \mathrm{c}}$ levels were measured from a venous blood sample. $\mathrm{HbA}_{1 \mathrm{c}}$ level was measured by the HPLC method. In contrast, ACR was determined by analysis of a random urine sample using the immunometric assay method.

Data was analyzed using SPSS and displayed in tables. The normality test was conducted through the Shapiro-Wilk test $(p>0.05)$ in order to determine the average of the normal distribution of the data, which is then presented as mean \pm SD. The result of the normality test was used for the next analysis; parametric analysis was used for normal distribution; otherwise, non-parametric analysis was used. ANOVA statistical analysis was performed to indicate the correlation between each group of ACR with the risk parameter of DN development.

The results in Table 1 showed that the majority of DM patients are female (as many as 69 subjects $(77.5 \%)$ ), mostly in the $46-55$ years group (as many as 37 subjects $(41.6 \%)$ ) and had normal nutritional status (44 subjects (49.4\%)). Based on the duration of illness, more than half of the subjects had DM for $1-5$ years (as many as 47 people $(52.8 \%)$ ). A majority of the subjects did not have a family history of DM (as many as $53(59.6 \%))$. Based on the history of treatment, 50 subjects had been treated with conventional treatment to control their BGL by using glibenclamide, metformin and a combination of glibenclamide and metformin (29.2\%, $22.5 \%$ and $4.5 \%$ respectively).

\section{Results}

\begin{tabular}{|c|c|c|}
\hline Characteristics & Frequency $(n)$ & Percentage (\%) \\
\hline $\begin{array}{l}\text { Gender } \\
\text { male } \\
\text { female }\end{array}$ & $\begin{array}{l}20 \\
69\end{array}$ & $\begin{array}{l}22.5 \\
77.5\end{array}$ \\
\hline $\begin{array}{l}\text { Age, years (mean, SD) } \\
\text { Age group } \\
<36 \text { years } \\
36-45 \text { years } \\
46-55 \text { years } \\
56-65 \text { years } \\
>65 \text { years }\end{array}$ & $\begin{array}{l}55.2(8.9) \\
1 \\
12 \\
37 \\
29 \\
10 \\
\end{array}$ & $\begin{array}{l}1.1 \\
13.5 \\
41.6 \\
32.6 \\
11.2 \\
\end{array}$ \\
\hline $\begin{array}{l}\text { Nutritional status } \\
\text { mild thinness } \\
\text { normal } \\
\text { grade } 1 \text { overweight } \\
\text { grade } 2 \text { overweight } \\
\text { grade } 3 \text { overweight }\end{array}$ & $\begin{array}{l}3 \\
44 \\
25 \\
14 \\
3 \\
\end{array}$ & $\begin{array}{l}3.4 \\
49.4 \\
28.1 \\
15.7 \\
3.4\end{array}$ \\
\hline $\begin{array}{l}\text { Duration of illness } \\
\text { (mean, SD) years } \\
\quad<1 \text { year } \\
1-5 \text { years } \\
6-10 \text { years } \\
>10 \text { years }\end{array}$ & $\begin{array}{l}4.4(4.3) \\
18 \\
47 \\
16 \\
8 \\
\end{array}$ & $\begin{array}{l}20.2 \\
52.8 \\
18.0 \\
9.0\end{array}$ \\
\hline $\begin{array}{l}\text { History of diabetes } \\
\text { father } \\
\text { mother } \\
\text { father and mother } \\
\text { none }\end{array}$ & \begin{tabular}{|l|}
17 \\
17 \\
2 \\
53 \\
\end{tabular} & $\begin{array}{l}19.1 \\
19.1 \\
2.2 \\
59.6\end{array}$ \\
\hline $\begin{array}{l}\text { Medical history } \\
\text { oral medicine } \\
\text { Metformin } \\
\text { Glibenclamide } \\
\text { Metformin + glibenclamide } \\
\text { not taking medicine } \\
\text { herbal/traditional medicine } \\
\text { insulin injection }\end{array}$ & $\begin{array}{l}20 \\
26 \\
4 \\
6 \\
32 \\
1\end{array}$ & $\begin{array}{l}22.5 \\
29.2 \\
4.5 \\
6.7 \\
36.0 \\
1.1\end{array}$ \\
\hline
\end{tabular}

Table 2. Glycemic and metabolic control in type 2 DM patients

\begin{tabular}{|l|l|l|l|l|}
\hline Parameter & Mean & SD & Min & Max \\
\hline Age & 55.20 & 8.92 & 35 & 79 \\
\hline Duration of illness & 4.43 & 4.3 & 1 & 18 \\
\hline TD systole $(\mathrm{mm} \mathrm{Hg})$ & 150.9 & 22.1 & 98 & 216 \\
\hline BGL $(\mathrm{mg} / \mathrm{dl})$ & 285.6 & 137.4 & 73 & 610 \\
\hline $\mathrm{HbA}_{1 \mathrm{c}}(\mathrm{mg} / \mathrm{dl})$ & 9.04 & 2.7 & 7.8 & 14.7 \\
\hline Total cholesterol $(\mathrm{mg} / \mathrm{dl})$ & 220.1 & 42.1 & 136 & 335 \\
\hline $\mathrm{HDL}-\mathrm{C}(\mathrm{mg} / \mathrm{dl})$ & 46.7 & 11.7 & 24 & 77 \\
\hline LDL-C (mg/dl) & 126.4 & 34.7 & 51 & 249 \\
\hline Triglyceride (TG) & 244.4 & 124.0 & 77 & 708 \\
\hline $\begin{array}{l}\text { ACR (mg albumin/gram } \\
\text { creatinine) }\end{array}$ & 164.5 & 371.6 & 3 & 2133 \\
\hline
\end{tabular}

Table 3 showed that there was a relationship between increased ACR levels with $\mathrm{BGL}, \mathrm{HbA_{1c^{ \prime } }} \mathrm{HDL}-\mathrm{C}$ and triglyceride (TG) $(p<0.05)$. In contrast, age, duration of illness, systole BP, total cholesterol and LDL-C levels did not correlate with increased ACR levels $(p>0.05)$. 


\begin{tabular}{|c|c|c|c|c|}
\hline \multirow[t]{2}{*}{ Risk Factors } & \multicolumn{3}{|c|}{ Mean albumin-to-creatinine ratio (ACR) (mg/g) } & \multirow[t]{2}{*}{$p$} \\
\hline & $\begin{array}{l}\text { Normal to mildly increased } \\
(n=49)\end{array}$ & $\begin{array}{l}\text { Moderately increased } \\
(n=26)\end{array}$ & $\begin{array}{l}\text { Severely increased } \\
(n=14)\end{array}$ & \\
\hline Age & 53.9 & 56.4 & 57.7 & 0.27 \\
\hline Duration of illness & 3.6 & 5.7 & 4.6 & 0.13 \\
\hline Systole BP (mm Hg) & 147.9 & 153.2 & 157.4 & 0.31 \\
\hline BGL (mg/dl) & 245.2 & 340.2 & 312.6 & $0.01^{*}$ \\
\hline $\mathrm{HbA}_{1 \mathrm{c}}(\mathrm{mg} / \mathrm{dl})$ & 8.2 & 10.4 & 9.3 & $0.03^{*}$ \\
\hline Total cholesterol (mg/dl) & 221.7 & 217.4 & 222.4 & 0.90 \\
\hline $\mathrm{HDL}-\mathrm{C}(\mathrm{mg} / \mathrm{dl})$ & 49.4 & 41.0 & 47.9 & $0.01 *$ \\
\hline LDL-C (mg/dl) & 127.9 & 123.3 & 127.2 & 0.86 \\
\hline Triglyceride (TG) & 227.1 & 289.9 & 219.9 & $0.04 *$ \\
\hline
\end{tabular}

\section{Discussion}

The results of this study indicate that age and duration of illness have a weak correlation with an increase in ACR. The results of this study are in line with another research [11], while the results of this study contradict several previous studies, which stated that age and duration of illness had an effect on ACR and were a recoil for the occurrence of DR [12-15]. Previous studies stated that the longer a patient suffers from DM, the more likely he is to experience complications of DN. It is stated that after 15 years of suffering from illness, the risk will be even greater [12]. The results of this study showed that this was not related, because the patients who took part in this study had an average duration of illness of around 1-5 years; so it could be that there were not many kidney disorders, even though 14 patients had a severe increase in ACR, but it was not statistically significant. It is recommended that a repeat examination be carried out to ensure a patient's kidney abnormalities; if necessary, a 24-hour urine examination for a definite diagnosis of DN (gold standard) is recommended.

The results showed that blood pressure was not associated with increased ACR. This study's results were not in line with several other studies, which stated that hypertension is a risk of increased ACR [11-14]. ND is a microvascular disorder and is microscopically characterized by a thickening of basement membrane capillaries [15]. The pathophysiology of ND begins with the increasing of vascular permeability. The increase in selective permeability to albumin in early ND is due to a loss of polarity along the glomerular basement membrane. The initiation of proteinuria is associated with poor glucose control, diabetes duration and hypertension [16].

The results of this study found that the majority of patients' blood pressure was still within normal limits, though some tended to increase. In general, this occurred with mild hypertension, so statistically, it did not affect their ACR. The results of this study indicate that an increase in ACR is associated with an increase in $\mathrm{BGL}$ and $\mathrm{HbA}_{11}$; several other studies also stated the same findings [11-13]. Poor metabolic control is an essential etiology of diabetic nephropathy. The risk of microvascular complications, including nephropathy in DM patients, will be decreased if $\mathrm{HbA}_{1 c}$ is < 7\% [17]. Glucose is considered a useful and clinically relevant marker of metabolic disorders leading to nephropathy, as demonstrated by the Diabetes Control and Complications Trial Research Group (DCCT). Furthermore, another study showed that lowering the serum glucose level will decrease the development of nephropathy [18].

The results showed that there is a relationship between HDL-C and TG levels with increased ACR; several previous studies also showed that microalbuminuria was positively related to age, body mass index (BMI), the presence of hypertension, duration of diabetes, glycated hemoglobin, fasting plasma glucose level, LDL-C, blood urea, serum creatinine and creatinine clearance $[11-14,19]$. However, other studies suggest no relationship between age, creatinine levels, high-density lipoproteins and triglycerides [12]. This condition is associated with the abnormality of kidney blood vessels due to dyslipidemia. Another study showed a positive correlation between blood pressure and lipid profile, suggesting that screening for microalbuminuria is essential for intervention and prevention of further complications, such as end-stage renal disease and cardiovascular diseases [20]. Microalbuminuria is a marker of cardiovascular disease risk and should be monitored per guidelines once or twice a year for progression to macroalbuminuria and kidney disease development, especially if plasma glucose, lipids and blood pressure are at guideline goals.

Microalbuminuria can be used as an independent marker for early prediction of cardiovascular complications and can be used as a screening procedure in all patients diagnosed with T2DM $[18,21]$. Determining a patient's ACR will provide an overview of other complications besides DN that can developed in T2DM patients.

\section{Conclusions}

This study showed that $\mathrm{BGL}, \mathrm{HbA}, \mathrm{HDL}-\mathrm{C}$ and triglyceride had a strong relationship with the occurrence of DN. In contrast, age, duration of diabetes, systolic blood pressure, total cholesterol and LDL-C levels had no relationship. Microalbuminuria can be a screening tools for complications of T2DM and can also be used to determine the occurrence of other complications of T2DM, such as cardiovascular complications and retinopathy.

Source of funding: This study was supported by the Ministry of Research and Technology/National Agency for Research and Innovation through DRPM programmed 2020 scheme with given contract No: 11/AMD/E1/KP.PTNBH/2020.

Conflicts of interest: The authors declare no conflicts of interest.

\section{References}

1. Tuttle KR, Bakris GL, Bilous RW, et al. Diabetic kidney disease: a report from an ADA Consensus Conference. Am J Kidney Dis 2014; 64(4): 510-533.

2. Indonesia PE. Pengelolaan dan pencegahan diabetes melitus tipe 2 di Indonesia. Jakarta: PB Perkeni; 2015 (in Indonesian).

3. Liu LH, Guo QY, Li CY, et al. Novel biomarkers for early diagnosis and progression of diabetic nephropathy. IJDE 2015; 1(1): 14-30. 
4. Kamijo-lkemori A, Sugaya T, Kimura K. Novel urinary biomarkers in early diabetic kidney disease. Curr Diab Rep 2014; 14(8): 513, doi: 10.1007/s11892-014-0513-1.

5. Shanmugasundaram K. Correlation between microalbuminuria and atherogenic index in evaluating coronary vascular risk in newly diagnosed type 2 diabetes [Doctoral dissertation]. Asaripallam: Kanyakumari Government Medical College Hospital; 2019.

6. Kouri TT, Viikari JS, Mattila KS, et al. Microalbuminuria: invalidity of simple concentration-based screening tests for early nephropathy due to urinary volumes of diabetic patients. Diabetes Care 1991; 14(7): 591-593.

7. McFarlane P, Cherney D, Gilbert RE, et al. Chronic kidney disease in diabetes. Can J Diabetes 2018; 42: S201-S209.

8. Oh TR, Choi HS, Kim CS, et al. Association between health related quality of life and progression of chronic kidney disease. Sci Rep 2019; 9(1): 1-9.

9. Rosenstock JL, Pommier M, Stoffels $\mathrm{G}$, et al. Prevalence of proteinuria and albuminuria in an obese population and associated risk factors. Front Med 2018; 5: 122, doi: 10.3389/fmed.2018.00122.

10. Maclsaac RJ, Ekinci El, Jerums G. Markers of and risk factors for the development and progression of diabetic kidney disease. Am $J$ Kidney Dis 2014; 63(2): S39-S62.

11. Ufuoma C, Ngozi JC, Kester AD, et al. Prevalence and risk factors of microalbuminuria among type 2 diabetes mellitus: a hospital-based study from, Warri, Nigeria. Sahel Med J 2016; 19(1): 16, doi: 10.4103/1118-8561.181889.

12. AlFehaid AA. Prevalence of microalbuminuria and its correlates among diabetic patients attending diabetic clinic at National Guard Hospital in Alhasa. J Family Med Prim Care 2017; 24(1): 1, doi: 10.4103/2230-8229.197174.

13. Bakris GL, Molitch M. Microalbuminuria as a risk predictor in diabetes: the continuing saga. Diabetes Care 2014; $37(3): 867-875$.

14. Marak AR, Chettiar S, Nambiar R. Microalbuminuria in normotensive type 2 diabetic patients. Sch J App Med Sci 2017; 5(11F): 4742$-4745$.

15. Schofield JD, Liu Y, Rao-Balakrishna P, et al. Diabetes dyslipidemia. Diabetes Ther 2016; 7: 203-219.

16. Aman M, Rasyid H, Dwi Sartika S, et al. Albumin excretion rate among patients with diabetic retinopathy. Caspian J Intern Med 2020; 11(2): 177-182.

17. American Diabetes Association. Standards of Medical Care in Diabetes - 2020 abridged for primary care providers. Clin Diabetes 2020; 38(1): 10-38.

18. Amelia R, Damanik HA, Lindarto $\mathrm{D}$, et al. The correlation between the level of $\mathrm{HbA}_{1 \mathrm{c}}$ with total serum cholesterol of uncontrolled type 2 diabetes mellitus patients in Binjai, Sumatera Utara. Advanced Science Letters 2017; 23(4): 3610-3613.

19. Romero-Aroca P, Mendez-Marin I, Baget-Bernaldiz M, et al. Review of the relationship between renal and retinal microangiopathy in diabetes mellitus patients. Curr Diabetes Rev 2010; 6(2): 88-101.

20. Sigdel M, Rajbhandari N, Basnet S, et al. Microalbuminuria among type-2 diabetes mellitus patients in Pokhara, Nepal. Nepal Med Coll J 2008; 10(4): 242-245.

21. Jung $\mathrm{CH}$, Mok JO. Recent updates on vascular complications in patients with type 2 diabetes mellitus. J Clin Endocrinol Metab 2020; 35(2): 260-271.

Tables: 3

Figures: 0

References: 21

Received: 17.09 .2020

Reviewed: 22.11 .2020

Accepted: 14.02 .2021

Address for correspondence:

Rina Amelia, MD, PhD

Department of Community Medicine and Public Health

Faculty of Medicine

Universitas Sumatera Utara

Jl. dr. Mansyur No.5 Kampus USU Medan

20155 Medan

Indonesia

Tel.: +62 8126444284

E-mail: rina2@usu.ac.id 